\title{
Factors affecting the turnover intention among employees in Penang manufacturing industry
}

\author{
Tin Phang Ooi ${ }^{*}$, Kok Ban Teoh ${ }^{2}$
}

BSc (Hons) Business \& Management from University of Salford, United Kingdom, residing at

SENTRAL College Penang, Malaysia ${ }^{1}$

SENTRAL College Penang, Malaysia ${ }^{2}$

sc02190043bbm@sentral.edu.my ${ }^{*}$,drderickteoh@gmail.com ${ }^{2}$

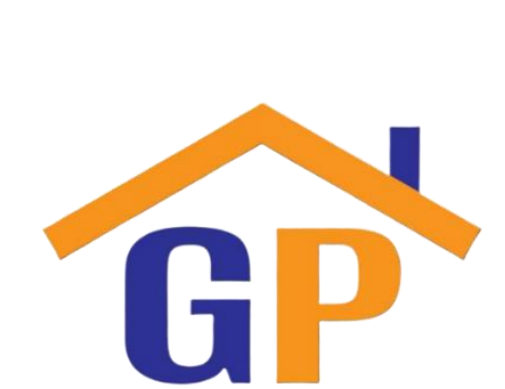

Article History

Received on 7 January 2021

$1^{\text {st }}$ Revision on 15 January 2021

$2^{\text {nd }}$ Revision on 18 January 2021

Accepted on 19 January 2021

\begin{abstract}
Purpose: The objective of the present study is to examine how work engagement, job demands and organizational commitment affect turnover intention among employees in Penang manufacturing industry.
\end{abstract}

Research Methodology: Quantitative approach was used in this study by distributing the online questionnaire to collect data from a sample of 75 employees drawn from manufacturing companies in Penang, Malaysia.

Results: The present study found out that work engagement and job demands have no significant relationship with turnover intention. Besides, the present study indicates that organizational commitment is negatively related to turnover intention.

Limitations: In this research, only 75 employees from Penang manufacturing industry had participated in the study. Since this small number of employees could not represent the entire Malaysia population, future research should expand to involve a bigger sample of employees from Malaysia manufacturing industry to collect more reliable results.

Contribution: The findings of this research provide benefits to the Federation of Malaysian Manufacturing (FFM) and manufacturing companies as they can understand the devastating effects of turnover and be equipped with strategies to decrease the turnover rate.

Keywords: Employee, Job demands, Manufacturing industry, Organizational commitment, Turnover intention, Work engagement

How to cite: Ooi, T. P., \& Teoh, K. B. (2021). Factors affecting the turnover intention among employees in Penang manufacturing industry. Annals of Human Resource Management Research, 1(1), $29-40$.

\section{Introduction}

The purpose of the present study is to identify the factors that affect the turnover intention among employees from Penang manufacturing industry. The manufacturing industry is very important and often acts as a crucial role in economy because of its contribution on economic growth in developing countries (Haruguchi, Charles \& Smeets, 2017). Herman (2016) has stated that manufacturing industry has created the basis of many national economies as manufacturing industry has provided high share of total output, employment, and revenue, that make it a very important factor in creating a sustainable economic growth. Besides, Kurniati and Yanfitri (2010) has mentioned that manufacturing industry has made a significant contribution to the economy which makes it an inseparable factor in the economic cycle. Kaldor (1969) also stated manufacturing industry is important in economic growth and characterized as the main engine of fast growth. 
Turnover intention can be referred to the likeliness of an employee to leave his or her current job position (Ngamkroeckjoti, Ounprechavanit \& Kijboonchoo, 2012). Yankeelov, Barbee, Sullivan and Antle (2008) has also stated that turnover intention can be explained as a situation where an employee leaves the organization due to several reasons. According to Kumar (2011) and Hassan (2014), turnover is a crucial issue for human resource department in every sector of the economy as it could affect the productivity and service quality. According to Holtom, Mitchell, Lee and Eberly (2008), when an employee decides to leave the organization, it would affect the company's cost and result in the loss of the company's competitive advantages. A few researchers stated that company could experience a poor performance in terms of profit due to the high turnover rate (Barrows, 1990; Hogan, 1992; Wasmuth \& Davis, 1993). Therefore, many researchers such as scholars, academics and managers have focused on the turnover intention among employees as an important concern due to its depressing impact (Mamun \& Hasan, 2017).

According to Bares (2017), the turnover rate of manufacturing industry around the world in 2016 was $16 \%$, and this is the fifth highest among all industries. Munir and Tobi (2020) also stated that the turnover intention of employees has become a serious issue in developing countries including Malaysia. They further added that manufacturing industry shows a higher turnover intention compared to other sectors due to its working environment. Moreover, prior studies have stated that Malaysia manufacturing industry has suffered a high turnover rate (Chin, 2018; Zaiuddin, Mad Nor \& Johari, 2015). This statement is further supported by Othman, Alias, Ariadi, Abdullah, Koe, Ismail and Ridzuan (2017) who stated that Malaysia manufacturing industry is struggling to reduce the turnover rate among employee.

In the present study, a total of three potential factors will be used to examine its relationship with the turnover intention. The potential factors that could affect the turnover intention are work engagement

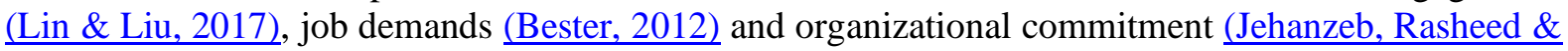
Rasheed, 2013). Therefore, the present research focused on the effects of work engagement, job demands, and organizational commitment on turnover intention among employees from Penang manufacturing industry.

\section{Literature review and hypotheses development}

\subsection{Turnover intention}

According to Ngamkroeckjoti, Ounprechavanit and Kijboonchoo (2012), turnover intention is the likeliness of an employee's intention to leave the current job Chang, Black and William (2013). further explained that turnover intention is the willingness of an employee to leave his or her current organization. Turnover intention could occur when there are lack of motivation, promotion and performance in the workplace, which results in the employee to quit the job and leave the organization (Bhayo, Shah \& Chachar, 2017).

Moreover, turnover can be separated into two categories, voluntary and involuntary turnover (Alias, Rohmanan, Ismail, Koe \& Othman, 2018). According to Bebe (2016), voluntary turnover is the situation that an employee quits the organization intentionally while involuntary turnover is the situation that an employee quit the company unwillingly and was forced to resign from his or her position due to several factors such as poor performance.

\subsection{Work engagement}

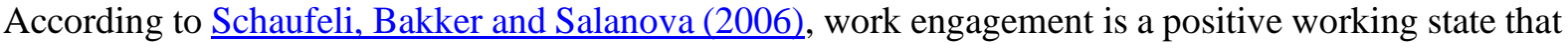
consists of vigor, dedication and absorption. Vigor can be defined as the high level of energy in work; dedication is referred as the high involvement of an individual in work; and absorption can be comprehended as the state of an individual being fully focused on work (Ahmad, Saffardin \& Teoh, 2020). The presence of these three factors could create engaged employees who possess high levels of energy and are fully immersed in their work. Shropshire and Kadlec (2013) defined work engagement as the positive relationship between one's energy and his or her psychological attachment towards the performance of the related job. Kunte and Rungruang (2019) further explained that work engagement 
is very important for organizations as employers need to identify the meaning of aspects of work so that they could create a more energized and engaged working environment for their employees.

\subsection{Job demands}

According to Bakker, Demerouti, Boer and Schaufeli (2003), job demands consist of the psychological, social and organizational aspects of the job that need an individual's physical and psychological efforts. Although majority of the job stress models indicated that job demands may bring adverse implication (Karasek, 1979; Bakker \& Demorouti, 2007), other research studies have found out that certain job demands could bring positive results such as motivation (LePine, LePine \& Jackson, 2014). Job demands can be further categorized into challenge and hindrance demands (Cavanaugh, Boswell, Roehling \& Bondreau, 2000). Challenge demands are referred to the job demands that could benefit the employees while hindrance demands are referred to the job demands that could harm the employees (Teoh \& Kee, 2018; Teoh \& Kee, 2019; Teoh \& Kee, 2020). However, the general job demands, such as role conflict, role overload and job ambiguity (De Jong \& Janssen, 2005; Hardy \& West, 2000), were focused in the study to determine its impact on the turnover intention.

\subsection{Organizational commitment}

Meyer, Allen and Smith (1993) defined organizational commitment as an individual's psychological state that connects employees to their organization. Porter, Steers, Mowday and Boulian (1974) also stated that organizational commitment is the employee's commitment to the organization. According to Meyer and Allen (1991), organizational commitment can be divided into three categories, that are affective commitment, continuance commitment and normative commitment. Affective commitment can be understood as an employee's decision to stay in the organization due to their own willingness; continuance commitment is defined as the employee's decision to stay in the organization due to financial support from the organization; and normative commitment refers to the employee's decision to remain in the organization as he or she feels obligated to do so because of the support provided by the organization.

\subsection{Relationship between work engagement and turnover intention}

According to Lin and Liu (2017), work engagement has a negative relationship with turnover intention. Abraham (2012) also stated that work engagement can be used to predict turnover intention. When an employee is fully immersed in his or her work, they would not leave their current job (Khan, 1990). This statement is supported by $\underline{\text { Saks (2006) }}$ who stated that when an employee is occupied with positive energy and fully immersed in his or her work, he or she tends to have no time and space to think of negative thought, such as having thought to quit the organization. Freene and Tiernan (2006) further explained that when employees know what they need to do in work, they would tend to have a high satisfaction level and thus reducing their turnover intention. Based on the discussion above, the following hypothesis is formed:

H1: Work engagement has a significant negative relationship with turnover intention.

\subsection{Relationship between job demands and turnover intention}

According to previous researches, job demands have a positive relationship with turnover intention (Asiwe, Hill \& Jorgensen, 2015; Houkes, Janssen, De Jonge \& Bakker, 2003). When the workload of employees is overloaded and they are not capable of handling the tasks, it would lead to job stress (French \& Caplan, 1972) and followed by turnover intention (Houkes et al., 2003). Moreover, Maslach, Jackson and Leiter (1996) have indicated that during the presence of specific job demands such as work overloaded and absence of specific job resources, it would lead to burnout and result in employee's turnover. Furthermore, according to Leo, González-Ponce, Sánchez-Miguel, Ivarsson and García-Calvo $\underline{(2015)}$, one of the job demands, that is role ambiguity, could result in low level of confidence among employees and lead to high turnover. Meanwhile, role ambiguity can also cause high turnover intention among employees when they are unsure about the expectation of supervisors in the organization. As a result, the following hypothesis is postulated:

H2: Job demands have a significant positive relationship with turnover intention. 


\subsection{Relationship between organizational commitment and turnover intention}

Previous research had found out that organizational commitment has a negative relationship with turnover intention (Jehanzeb, Rasheed \& Rasheed, 2013). According to Tnay, Othman, Siong and Lim (2013), when the employees' values are similar with the organization's goals, it would result in their willingness to stay in the organization instead of leaving. Smith (1996) has mentioned that when an employee is satisfied with the organization, he or she tends to be more committed towards the organization. On the contrary, employees who are dissatisfied with the organization, they will tend to have the turnover intention by having plan to leave their current organization. Meyer and Allen (1997) further explained that when employees are committed towards the organization, they are willing to contribute beyond their minimum duties at work and increase the likeliness to stay in the organization. Based on the discussions above, the following hypothesis is forwarded:

H3: Organizational commitment has a significant negative relationship with turnover intention.

\subsection{Research framework}

Figure 1 indicates the research framework used in the present study. The independent variables include work engagement, job demands and organizational commitment whereas the dependent variable is turnover intention.

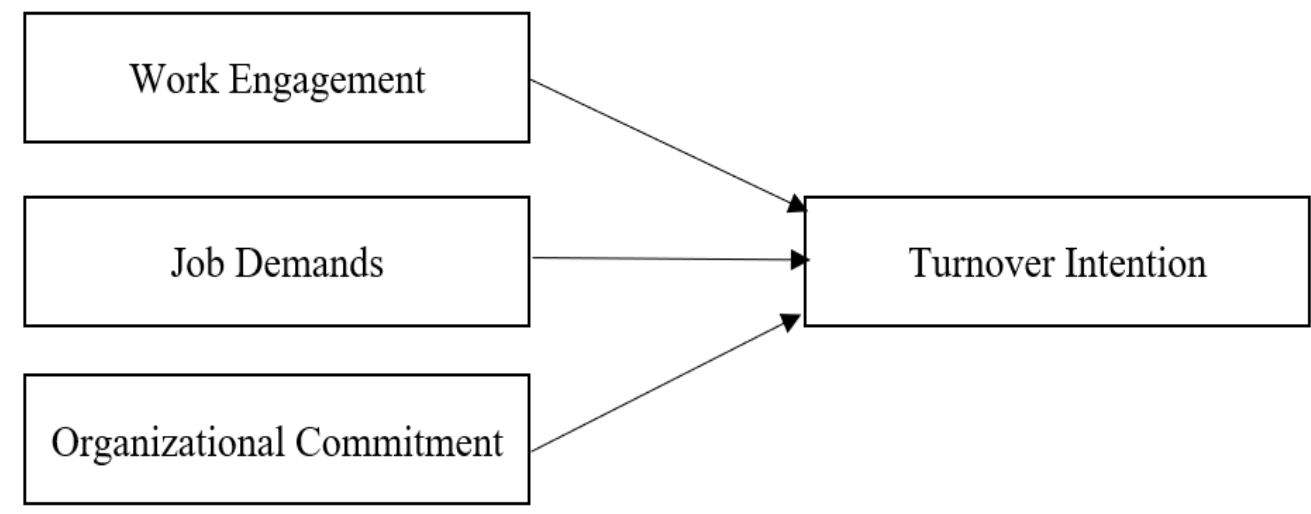

Figure 1: Research Framework

\section{Research methodology}

\subsection{Study design}

The present study uses quantitative research method to examine the relationship between the independent variables and dependent variable. According to Aliaga and Gunderon (2002), quantitative research method is a research method that gathers information in numerical form and analyze it with statistical methods. Furthermore, Williams (2007) had stated that the steps in conducting a quantitative research are:

1. Develop a problem statement

2. Create research hypotheses

3. Conduct a literature review

4. Execute a quantitative analysis of data

The steps in conducting a quantitative research are aligned with the present study, therefore, quantitative research method is being adapted to examine the relationship of work engagement, job demands, organizational commitment and turnover intention.

\subsection{Sample}

The targeted population in this research includes all employees who are working in Penang manufacturing industry. In the present study, only full-time employees from Penang manufacturing industry who have been working more than one year were chosen to take part in this research. According to Emiroglu, Akova and Tanriverdi (2015), employees who have lower working experience, such as 
one year, would tend to have higher turnover intention. Therefore, as a measure to avoid biasness in the data collected, employees who have been working for at least one year in Penang manufacturing industry were chosen to take part in this research.

The sampling technique used in this research is purposive sampling since there are criteria set for the samples, that are only full-time employees from Penang manufacturing industry who have been working for more than one year are eligible to take part in the present research. According to Maxwell (1996), purposive sampling is a sampling method where only certain criteria is selected deliberately to obtain the important information that could not be obtained from other choices. Patton (2002) has stated that purposive sampling is mostly used in quantitative research since this research method requires only certain information to conduct the research. As the research method used in the present study is quantitative research method, therefore purposive sampling would be the best sampling method to be adopted. Besides, the respondents in this research had to fulfill the selected criteria, that are full-time employees who have been working for more than one year in the Penang manufacturing industry, thus once again purposive sampling the most suitable sampling method to be adopted.

The minimum sample size in this research study is set at 50 employees. The online questionnaire is distributed to full-time employees who are employed for at least one year in the Penang manufacturing industry. A total of 75 respondents were collected at the end of the data collection period. According to Rocoe (1975), most behavioral studies required at least a sample size of 30. Therefore, the sample collected in this research are appropriate to proceed with the data analysis.

\subsection{Data collection method}

Primary data was obtained through the use of the online questionnaire by distributing it to full-time employees who have been working more than one year in Penang manufacturing industry. Firstly, an online questionnaire based on all variables is created by using Google Form. Next, the present researchers shared the questionnaire link in various social media platform including Facebook, Instagram and Telegram. After one week, the present researchers checked the progress of the respondents. Since, the responses are still not satisfactory, the present researchers contacted their network to share the online questionnaire link again. Besides, the present researchers also obtained the email addresses of Penang manufacturing companies and sent them a cover letter to request for their participation in the survey. After another one week, the present researchers checked and recorded the submitted responses. At the end of two weeks, the researcher collected 75 responses and the data collection period ended.

\subsection{Research instruments}

The research questionnaire consists of a cover letter and 5 sections. Section A measures work engagement in the workplace, Section B measures job demands in the workplace, Section C measures organizational commitment in the workplace, Section D measures turnover intention in the workplace and Section E collects the demographic data of respondents.

To measure work engagement, the measurement developed by Schaufeli, Shimazu, Hakanen, Salanova and De Witte (2017) was used and there are total of 3 items. The measurement for work engagement was measured with a 7-point Likert scale, ranging from 1(Never) to 7(Every Day). For job demands, the measurement by Martin, Salanova and Peiro (2007) was used and there are total of 7 items. The measurement for job demands was measured with a 5-point Likert scale, ranging from 1(None) to 5(A Great Deal). The measurement by Mowday, Steers and Porter (1979) was used to measure organizational commitment and there are total of 15 items. The measurement for organizational commitment was measured with a 5-point Likert scale, ranging from 1(Strongly Disagree) to 5(Strongly Agree). Lastly, the measurement by Mobley, Horner and Hollingsworth (1978) was used to measure turnover intention and there are total of 3 items. The measurement for turnover intention was measured with a 5-point Likert scale, ranging from 1(Strongly Disagree) to 5(Strongly Agree). 
Hence, the summary of all research instruments used in the present study is presented at Table 1.

Table 1

Research Instrument

\begin{tabular}{|l|c|c|l|}
\hline \multicolumn{1}{|c|}{ Variables } & Items & Cronbach's alpha & \multicolumn{1}{c|}{ Sources } \\
\hline Turnover Intention & 3 & 0.90 & $\underline{\underline{\text { Mobley, Horner and Hollingsworth }}}$ \\
\hline Work Engagement & 3 & 0.95 & $\underline{\underline{\text { (1978) }}}$ \\
\hline Job Demaufeli, Shimazu, Hakanen, \\
\hline Organizanova and De Witte (2017)
\end{tabular}

\section{Results and discussions}

\subsection{Result}

The respondents in this study are full-time employees from Penang manufacturing industry who have been working for more than one year. A total of 200 questionnaires was distributed and 75 questionnaires were collected, which indicates a $37.5 \%$ of response rate. Table 2 shows the demographic data of respondents, where the majority of respondents were female $(54.7 \%)$, aged from $26-35$ years old $(61.3 \%)$, were working at least 1 year to 5 years $(58.7 \%)$, and were Diploma graduates $(73.3 \%)$.

\section{Table 2}

Respondents' Profile

\begin{tabular}{|c|c|c|c|}
\hline Demographic variable & Category & Frequency & Percentage \\
\hline Gender & $\begin{array}{l}\text { Male } \\
\text { Female }\end{array}$ & $\begin{array}{l}34 \\
41\end{array}$ & $\begin{array}{l}45.3 \\
54.7\end{array}$ \\
\hline Age & $\begin{array}{l}18-25 \text { years old } \\
26-35 \text { years old } \\
36-45 \text { years old } \\
46-55 \text { years old } \\
56 \text { years old and above }\end{array}$ & $\begin{array}{c}7 \\
46 \\
20 \\
1 \\
1\end{array}$ & $\begin{array}{c}9.3 \\
61.3 \\
26.7 \\
1.3 \\
1.3\end{array}$ \\
\hline Ethnic & $\begin{array}{l}\text { Malay } \\
\text { Chinese } \\
\text { Indian } \\
\text { Other }\end{array}$ & $\begin{array}{c}1 \\
72 \\
0 \\
2\end{array}$ & $\begin{array}{c}1.3 \\
96.0 \\
0 \\
2.7\end{array}$ \\
\hline Marital Status & $\begin{array}{l}\text { Single } \\
\text { Married } \\
\text { Divorced } \\
\text { Widowed } \\
\text { Separated }\end{array}$ & $\begin{array}{c}43 \\
31 \\
1 \\
0 \\
0 \\
\end{array}$ & $\begin{array}{c}57.3 \\
41.3 \\
1.3 \\
0 \\
0 \\
\end{array}$ \\
\hline Experience & $\begin{array}{l}1-5 \text { years } \\
6-10 \text { years } \\
11-15 \text { years } \\
16-20 \text { years } \\
21 \text { years and above }\end{array}$ & $\begin{array}{c}44 \\
23 \\
3 \\
3 \\
2\end{array}$ & $\begin{array}{c}58.7 \\
30.7 \\
4.0 \\
4.0 \\
2.7 \\
\end{array}$ \\
\hline Education Level & $\begin{array}{l}\text { SPM } \\
\text { STPM } \\
\text { A-level/Foundation/Matriculation } \\
\text { Diploma } \\
\text { Bachelor's Degree } \\
\text { Master's Degree } \\
\text { Doctorate's Degree }\end{array}$ & $\begin{array}{c}2 \\
0 \\
5 \\
55 \\
10 \\
3 \\
0 \\
\end{array}$ & $\begin{array}{c}2.7 \\
0 \\
6.7 \\
73.3 \\
13.3 \\
4.0 \\
0\end{array}$ \\
\hline
\end{tabular}


Table 3 indicates the measurement model of the present research. As shown in Table 3, the AVEs are all greater than 0.5 and the CRs are all greater than 0.7. The loadings were also acceptable with only six loadings of organizational commitment lower than 0.708 (Hair, Risher, Sarstedt and Ringle, 2019).

Meanwhile, the HTMT values should be $\leq 0.85$ for the stricter criterion, and $\leq 0.90$ for the more lenient criterion. As indicated in Table 4, all HTMT values were lesser than 0.85 . Therefore, it can be concluded that respondents are aware that the 4 constructs were different. Based on these results, it is shown that the measurement models are both valid and reliable.

Table 3

Measurement Model

\begin{tabular}{|c|c|c|c|c|}
\hline Constructs & Items & Loadings & AVE & $\mathrm{CR}$ \\
\hline Work Engagement & $\begin{array}{l}\text { WE1 } \\
\text { WE2 } \\
\text { WE3 }\end{array}$ & $\begin{array}{l}0.844 \\
0.959 \\
0.959\end{array}$ & 0.850 & 0.944 \\
\hline Job Demands & $\begin{array}{l}\text { JD1 } \\
\text { JD2 } \\
\text { JD3 } \\
\text { JD4 } \\
\text { JD5 } \\
\text { JD6 } \\
\text { JD7 }\end{array}$ & $\begin{array}{l}0.831 \\
0.529 \\
0.849 \\
0.763 \\
0.842 \\
0.726 \\
0.663\end{array}$ & 0.564 & 0.899 \\
\hline Organizational Commitment & $\begin{array}{c}\text { OC1 } \\
\text { OC2 } \\
\text { OC4 } \\
\text { OC5 } \\
\text { OC6 } \\
\text { OC8 } \\
\text { OC10 } \\
\text { OC13 } \\
\text { OC14 }\end{array}$ & $\begin{array}{l}0.764 \\
0.857 \\
0.560 \\
0.785 \\
0.903 \\
0.911 \\
0.897 \\
0.724 \\
0.810\end{array}$ & 0.653 & 0.943 \\
\hline Turnover Intention & $\begin{array}{l}\text { TI1 } \\
\text { TI2 } \\
\text { TI3 }\end{array}$ & $\begin{array}{l}0.923 \\
0.952 \\
0.936\end{array}$ & 0.878 & 0.956 \\
\hline
\end{tabular}

Note: OC3, OC7, OC9, OC11, OC12, OC15 were deleted due to low loadings

Table 4

Discriminant Validity (HTMT)

\begin{tabular}{|l|c|c|c|c|}
\hline \multicolumn{1}{|c|}{ Variable } & 1 & 2 & 3 & 4 \\
\hline 1. Job Demands & & & & \\
\hline 2. Organizational Commitment & 0.682 & & & \\
\hline 3. Turnover Intention & 0.262 & 0.468 & & \\
\hline 4. Work Engagement & 0.406 & 0.431 & 0.225 & \\
\hline
\end{tabular}

Firstly, the effect of the 3 predictors on turnover intention was examined and showed that the R square as 0.224 , which indicates that all the 3 predictors explained $22.4 \%$ of the variance in turnover intention. As shown in Table 5, it is found that work engagements $(\beta=-0.033, \mathrm{p}>0.5)$ and job demands $(\beta=-$ $0.020, \mathrm{p}>0.5$ ) are not significantly related to turnover intention in this present study. Thus, $\mathrm{H} 1$ and $\mathrm{H} 2$ were not supported. However, organizational commitment $(\beta=-0.471, \mathrm{p}<0.5)$ was shown to have a significant positive relationship with turnover intention in the present study. Therefore, H3 was supported. 
Table 5

Hypothesis Testing Direct Effect

\begin{tabular}{|c|c|c|c|c|c|c|c|c|c|}
\hline Hypothesis & Relationship & $\begin{array}{c}\text { Std } \\
\text { Beta }\end{array}$ & $\begin{array}{c}\text { Std } \\
\text { Errors }\end{array}$ & $\begin{array}{c}\mathrm{t}- \\
\text { values }\end{array}$ & $\begin{array}{c}\mathrm{p}- \\
\text { values }\end{array}$ & $\begin{array}{c}\text { BCI } \\
\text { LL }\end{array}$ & $\begin{array}{c}\text { BCI } \\
\text { UL }\end{array}$ & $\mathrm{f}^{2}$ & VIF \\
\hline H1 & WE $\rightarrow$ TI & -0.033 & 0.103 & 0.321 & 0.748 & -0.213 & 0.227 & 0.001 & 1.224 \\
\hline H2 & JD $\rightarrow$ TI & -0.020 & 0.171 & 0.118 & 0.906 & -0.744 & 0.157 & 0.000 & 1.589 \\
\hline H3 & OC $\rightarrow$ TI & -0.471 & 0.158 & 2.976 & 0.003 & -0.736 & -0.160 & 0.166 & 1.715 \\
\hline
\end{tabular}

Note: We used $95 \%$ confidence interval with a bootstrapping of 5,000

\subsection{Discussion}

The purpose of the present study is to examine the effects of work engagement, job demands and organizational commitment on turnover intention. The result of this study indicated that work engagement and turnover intention did not have a significant relationship. This result can be explained where the high levels of work engagement among employees projected no effect on the turnover intention. However, this result is inconsistent with the previous study which stated that work engagement has a negative relationship with turnover intention (Lin \& Liu, 2017). Thus, H1 is not supported. This phenomenon can be explained as over half of the respondents in the present study are having 1 to 5 years of working experience (58.7\%) and it was once claimed by Emiroglu et al. (2015) that employees with lower working experience tend to experience turnover intention. As a result, work engagement does not play its role on turnover intention since the respondents in the present study are more towards lower working experience category. Therefore, work engagement has no effect on turnover intention of employees in Penang manufacturing industry.

In this research, job demands are not significantly related to turnover intention. The result explains that when the workload of an employee is high, it would not cause the increment of turnover intention among employees. Thus, $\mathrm{H} 2$ was not supported. The result of the present study is different with the previous studies where job demands are positively related to turnover intention (Asiwe et al., 2015; Houkes et al., 2003; Maslach et al., 1996). This occurrence can be understood from the perspective of teaching experience of the respondents in the present study. As discussed earlier, over half of the respondents are having 1 to 5 years of working experiences and undoubtedly, they tend to experience turnover intention easily regardless the levels of job demands. Therefore, job demands are not significantly related to turnover intention among employees in Penang manufacturing industry.

Lastly, the result of this research indicated that organizational commitment is negatively related to turnover intention. Thus, $\mathrm{H} 3$ was supported. The result of this study is aligned with previous study that organizational commitment has a negative significant relationship with turnover intention (Jehanzeb, Rasheed \& Rasheed, 2013). According to Tnay et al. (2013), employees tend to remain in the organization when their perceived values are aligned with the organization's goals and objectives. Lumley, Coetzee, Tladinyane and Ferreira (2011) further stated that when employees are having a decent relationship with the organization and a positive attitude towards the goals and values of the organization, they will tend to remain in the organization which they are currently working with. Besides, a number of researchers have also stated that when employees are satisfied and committed to their jobs, they will be less likely to resign from their job (DiPietro \& Bufquin, 2017; Kim \& Kao, 2014; Matz, Wells, Minor, \& Angel, 2013; Wang, Tsai, Lei, \& Lai, 2016). Moreover, when the employees are committed to the organization, they tend to contribute more than what they need to do at work, thus this increases their willingness to stay in the company (Meyer and Allen, 1997). Therefore, a high level of organizational commitment among Penang manufacturing industry employees can reduce their turnover intention.

\section{Conclusion}

The present study is very important as it examines the factors that affect the turnover intention in Penang manufacturing industry. In this present study, it was found that work engagement and job demands are not significantly related to turnover intention, which are different from the previous studies. However, 
organizational commitment was found to have a significant negative relationship with turnover intention. Thus, the management of the manufacturing companies should be aware in creating the working cultures which could fit well on employees with lower working experience so that they can be engaged with their work, and subsequently making them to have lower turnover intention. On the other hand, efforts can be focused to increase the employees' commitment towards the organization in order to avoid the experience of high turnover intention.

\section{Limitation and study forward \\ Managerial implication}

The findings of this research are significant because the value of organizational commitment is important to reduce the turnover intention among employees from Penang manufacturing industry. The result of this research could be beneficial to the Federation of Malaysian Manufacturers (FFM) and all the manufacturing companies in Malaysia as they could understand the nature and the factors which affect the turnover intention. Based on the findings in the present study, FFM and manufacturing companies in Malaysia could be equipped with strategies and planning to increase the employees' intention to retain in the company by creating a suitable working environment and culture that promote for organizational commitment. By aligning the company's goals together with the employees' value, it will significantly increase the employees' commitment towards the organization while reducing their likeliness to quit from their current serving organization.

\section{Limitation}

Although the result of the present study contributed to the existing literature, it is yet to be generalized to the entire population. The data collected in this present research is merely from Penang manufacturing industry with a sample size of 75 . Therefore, the results of the present study could not represent the opinions of employees from the entire Malaysia manufacturing industry. Therefore, this research should expand to the entire Malaysia manufacturing industry in the future so as to obtain a more representative sample to study the turnover intention among employees.

\section{References}

Abraham, S. (2012). Job satisfaction as an antecedent to employee engagement. SIES Journal of Management, 8(2), 27-36.

Ahmad, J., Saffardin, S. F., \& Teoh, K. B. (2020). How does job demands and job resources affect work engagement towards burnout? The case of Penang preschool. International Journal of Innovation, Creativity and Change, 12(5), 283-293.

Aliaga, M., \& Gunderson, B. (2002). Interactive Statistics. Thousand Oaks: Sage Publications.

Alias, N. E., Rohmanan, N. H., Ismail, S., Koe, W., \& Othman, R. (2018). Factors influencing turnover intention in a Malaysian manufacturing company. In: International Conference on Economics, Business and Economic Education. Semarang City: Knowledge E, 771-787.

Asiwe, D. N., Hill, C., \& Jorgensen, L. I. (2015). Job demands and resources of workers in a South African agricultural organization. SA Journal of Human Resource Management, 13(1), 1- 16.

Bakker, A. B., \& Demerouti, E. (2007). The job demands-resources model: State of the art. Journal of Managerial Psychology, 22, 309-328.

Bakker, A. B., Demerouti, E., Boer, E., \& Schaufeli, W. B. (2003). Job demands and job resources as predictors of absence duration and frequency. Journal of Vocational behavior, 62, 393-417.

Bares, A. (2017, April 21). 2016 Turnover Rates by Industry. Retrieved from https://www.compensationforce.com/2017/04/2016-turnover-rates-by-industry.html

Barrows, C. (1990). Employee turnover: implications for hotel managers. Hospitality Review, 8(1), 24 31.

Bebe, I. A. (2016). Employee Turnover Intention in the U. S. Fast Food Industry. PhD. Walden University.

Bester, F. (2012). A model of work identity in multicultural work settings. PhD. University of Johannesburg. 
Bhayo, A. R., Shah, N., \& Chachar, A. A. (2017). The impact of interpersonal conflict and job stress on employees turnover intention. International Research Journal of Arts and Humanities, 45(45), 179-190.

Cavanaugh, M.A., Boswell, W.R., Roehling, M.V., \& Boudreau, J.W. (2000). An empirical examination of self-reported work stress among U.S. managers. Journal of Applied Psychology, $85,65-74$.

Chang, Black, P., \& Wiliam, D. (2013). Inside the black box: Raising standards through classroom assessment. Wiley Online Library, 80(2), 139-148.

Chin, C. L. (2018). The influence of job satisfaction on employee turnover intention in the Manufacturing industry of Malaysia. Journal of Arts \& Social Sciences, 1(2), 53-63.

De Jong, S., \& Janssen, O. (2005). Innovative working behavior and stress as a response to role overload and role ambiguity. Gedrag en Organisatie, 18(2), 66-82.

DiPietro, R., \& Bufquin, D. (2017). Effects of work status congruence and perceived management concern for employees on turnover intentions in a fast casual restaurant chain. Journal of Human Resources in Hospitality \& Tourism, 17(1), 1-22.

Emiroglu, B. D., Akova, O., \& Tanriverdi, H. (2015). The relationship between turnover intention and demographic factors in hotel businesses: A study at five star hotels in Istanbul. Social and Behavioral Sciences, 207, 385-397.

Freene, Y., \& Tiernan, J. (2006). Employee engagement: An overview of the literature on the proposed antithesis of burnout. The Irish Journal of Psychology, 27, 130-141.

French, J. R. P., \& Caplan, R. D. (1972). Organization stress and strain. In A. J. Marrow, ed., The failure of success. New York: Amacom, 30-66.

Hair, J., Risher, J., Sarstedt, M., \& Ringle, C. (2019), When to use and how to report the results of PLSSEM. European Business Review, 31(1), 2-24.

Hardy, G. E., \& West, M. A. (2000). Interpersonal attachment and innovation at work. [Manuscript] University of Sheffield, Sheffield.

Haruguchi, N., Charles, F. C. C., \& Smeets, E. (2017). The importance of manufacturing in economic development: Has this changed? World Development, 93, 293-315.

Hassan, R. (2014). Factors influencing turnover intention among technical employees in information technology organization: A case of XYZ (M) Sdn Bhd. International Journal of Arts and Commerce, 3(9), 120-137.

Herman, E. (2016). The Importance of the Manufacturing Sector in the Romanian Economy. Procedia Technology, 22(1), 976-983.

Hogan, J. J. (1992). Turnover and what to do about it. Cornell Hospitality Quarterly, 33(1), 40-45.

Holtom, B. C., Mitchell, T., Lee, T., \& Eberly, M. (2008). Turnover and retention research: A glance at the past, a closer review of the present, and a venture into the future. The Academy of Management Annals, 2(1), 231-274.

Houkes, I., Janssen, P., De Jonge, J., \& Bakker, A.B. (2003). Specific determinants of intrinsic work motivation, emotional exhaustion and turnover intention: A multi-sample longitudinal study. Journal of Occupational and Organizational Psychology, 76, 427-450.

Jehanzeb, K., Rasheed, A., \& Rasheed, M. F. (2013). Organizational commitment and turnover intentions: Impact of employee's training in private sector of Saudi Arabia. International Journal of Business and Management, 8(8), 79-90.

Kahn, W. A. (1990). Psychological conditions of personal engagement and disengagement at work. The Academy of Management Journal, 33(4), 692-724

Kaldor, N. (1969). Strategic factors in economic development. Economic Development and Cultural Change, 17(2), 277-280.

Karasek, R. A. (1979). Job demands, job decision latitude, and mental strain: Implications for job redesign. Administrative Science Quarterly, 24(2), 285 -308.

Kim, H., \& Kao, D. (2014). A meta-analysis of turnover intention predictors among U.S. child welfare workers. Children and Youth Services Review, 47, 214-223.

Kumar, R. R. (2011). Turn over issues in the textile industry in Ethiopia: A case of arba minch textile company. African Journal of Marketing Management, 3, 32-44.

Kunte, M., \& Rungruang, P. (2019). Test of the job demand resources model in Thailand. International Journal of Organisation Theory \& Behaviour, 22(1), 2-21. 
Kurniati, Y., \& Yanfitri, Y. (2010). The dynamics of manufacturing industry and the response toward business cycle. Bulletin of Monetary Economics and Banking, 13(2), 131-164.

Leo, F. M., González-Ponce, I., Sánchez-Miguel, P. A., Ivarsson, A., \& García-Calvo, T. (2015). Role ambiguity, role conflict, team conflict, cohesion and collective efficacy in sports teams: A multilevel analysis. Psychology of Sport and Exercise, 20, 60-66.

LePine, J. A., LePine, M. A., \& Jackson, C. L. (2004). Challenge and hindrance stress: Relationships with emotional exhaustion, motivation to learn, and learning performance. Journal of Applied Psychology, 89(5), 883-891.

Lin, C. P., \& Liu, M. L. (2017). Examining the effects of corporate social responsibility and ethical leadership on turnover intention. Personnel Review, 46(3), 526-550.

Lumley, E. J., Coetzee, M., Tladinyane, R., \& Ferreira, N. (2011). Exploring the job satisfaction and organizational commitment of employees in the information technology environment. Southern African Business Review, 15, 100-118.

Mamun, C. A. A., \& Hasan, M. N. (2017). Factors affecting employee turnover and sound retention strategies in business organization: A conceptual view. Problems and Perspectives in Management, 15(1), 63-71.

Martin, P., Salanova, M., \& Peiro, J. M. (2007). Job demands, job resources and individual innovation at work: Going beyond Karasek's model. Psicothema, 19(4), 621-626.

Maslach, C., Jackson, S.E., \& Leiter, M. (1996). Maslach Burnout Inventory: Manual. Palo Alto, CA: Consulting Psychologists Press.

Matz, A. K., Wells, J. B., Minor, K. I., \& Angel, E. (2013). Predictors of turnover intention among staff in juvenile correctional facilities: The relevance of job satisfaction and organizational commitment. Youth Violence and Juvenile Justice, 11(2), 115-131.

Maxwell, J. A. (1996). Qualitative research design: An interactive approach. Thousand Oaks, CA: Sage Publications.

Meyer, J. P., \& Allen, N. J. (1991). A three-component conceptualization of organizational commitment. Human Resource Management Review, 1(1), 61-89.

Meyer, J., \& Allen, N. (1997). Commitment in the workplace. Thousand Oaks, CA: SAGE Publications.

Meyer, J. P., Allen, N. J., \& Smith, C. A. (1993). Commitment to organizations and occupations: Extension and test of a three-component conceptualization. Journal of Applied Psychology, 78(4), 538-551.

Munir, R., \& Tobi, S. N. M. (2020). Understanding and measuring he determinants of employees' turnover intention. Environment-Behavior Proceedings Journal, 5(13).

Mobley, W. H., Horner, S. O., \& Hollingsworth, A. T. (1978). An Evaluation of precursors of hospital employee turnover. Journal of Applied Psychology, 63, 408-414.

Ngamkroeckjoti, C., Ounprechavanit, P., \& Kijboonchoo, T. (2012). Determinant factors of turnover intention: A case study of air conditioning company in Bangkok, Thailand. In: International Conference on Trade, Tourism and Management. Bangkok: Planetary Scientific Research Center, 21-22.

Othman, R., Alias, N. E., Ariadi, N. S., Abdullah, A., Loon, K. W., Ismail, S., \& Ridzuan, A. R. (2017). Employee retention in emerging economy: A case of Gen Y in Malaysian manufacturing company. Advanced Science Letters, 23(8), 7637-7640.

Patton, M. Q. (2002). Qualitative research and evaluation methods. Thousand Oaks: Sage Publication.

Porter, L. W., Steers, R. M., Mowday, R. T., \& Boulian, P. V. (1974). Organizational commitment, job satisfaction, and turnover among psychiatric technicians. Journal of Applied Psychology, 59(5), 603-609.

Roscoe, J. T. (1975). Fundamental research statistics for the behavioral sciences. New York: Holt Rinehart and Winston.

Saks, A. M. (2006). Antecedents and consequences of employee engagement. Journal of Managerial Psychology, 21(7), 600-619.

Schaufeli, W. B., Bakker, A. B., \& Salanova, M. (2006). The measurement of work engagement with a brief questionnaire: A cross-national study. Educational and Psychological Measurement, 66, 701-716 
Shropshire, J., \& Kadlec, C. (2013). Where are you going? A comparative analysis of job and career change intentions among USA it workers. Journal of Internet Banking and Commerce, 17(2), 120.

Smith, D. (1996). Increasing employee productivity, job satisfaction, and organizational commitment. Hospital Health Service Administration, 41, 160-174.

Teoh, K. B., \& Kee, D. M. H. (2018). How does work engagement affect psychosocial safety climate and burnout? The case of the Malaysian research universities. Asia Proceedings of Social Sciences, 2(4), 60-64.

Teoh, K. B., \& Kee, D. M. H. (2019). Psychosocial safety climate and burnout: The mediating role of challenge and hindrance demands. Journal of Management and Marketing Review, 4(1), 92-99.

Teoh, K. B., \& Kee, D. M. H. (2020). Psychosocial safety climate and burnout among academicians: the mediating role of work engagement. International Journal of Society Systems Science, 12(1), $1-14$.

Tnay, E., Othman, A. E. A., Siong, H. C., \& Lim, S. L. O. (2013). The influences of job satisfaction and organizational commitment on turnover intention. Social and Behavioral Sciences, 97, 201208.

Wang, J. H., Tsai, K. C., Lei, L. J. R., \& Lai, S. K. (2016). Relationships among job satisfaction, organizational commitment, and turnover intention: Evidence from the gambling industry in Macau. Business and Management Studies, 2(1), 104-110.

Wasmuth, W. J., \& Davis, S. W. (1983). Managing employee turnover: why employees leave. Cornell Hospitality Quarterly, 11-18.

Williams, C. (2007). Research methods. Journal of Business \& Economics Research, 5(3), 65-72.

Yankeelov, P. A., Barbee, A. P., Sullivan, D., \& Antle, B. F. (2008). Individual and organizational factors in job retention in Kentucky's child welfare agency. Children and Youth Services Review, 31(5), 547-554.

Zainuddin, N., Mad Nor, N. N., \& Johari, H. (2015). Turnover intention (job characteristics perspective) among electrical and electronics sub-sector employees in Malaysia. Journal of Technology and Operations Management, 10(2), 106-119. 